\title{
PROFIL DESA WISATA SAMIRAN DI LERENG MERBABU-MERAPI KECAMATAN SELO KABUPATEN BOYOLALI PROPINSI JAWA TENGAH
}

\author{
Jaka Suyana* \\ Fakultas Pertanian, Universitas Sebelas Maret Surakarta
}

\begin{abstract}
Abstrak
Desa Wisata Samiran sudah dirintis sejak tahun 2006, berada di dataran tinggi lereng Merbabu-Merapi atau di lembah Gunung Merbabu-Merapi memiliki panorama alam yang indah dan udara sejuk. Secara administrasi berada diwilayah Kecamatan Selo Kabupaten Boyolali Propinsi Jawa Tengah, mempunyai luas 663,329 ha dengan elevasi 1.400-2.550 m dpl, jenis tanah andosol/andisols (lereng Merbabu) dan regosol/entisols (lereng Merapi). Dataran tinggi dengan tanah andosol secara agroklimat cocok/sesuai untuk pengembangan beraneka agrowisata, yaitu : tanaman perkebunan (teh dan kopi Arabika), tanaman buah (tledung, apel dan jeruk), tanaman hias, serta sayuran. Kegiatan pengabdian ini bertujuan untuk perintisan pendampingan pada kelompok tani di Desa Wisata Samiran. Jenis kegiatan yang dilakukan adalah pengumpulan data/informasi yang berkaitan dengan "Profil Desa Wisata Samiran", yaitu meliputi: (1) pengumpulan data/informasi kondisi agroklimat dan jenis usahatani; (2) pengumpulan data/informasi keberadaan dan kegiatan kelompok tani; serta (3) pengumpulan data/informasi keberadaan obyek wisata di wilayah Desa Wisata Samiran. Target dari kegiatan pengabdian ini diperoleh Profil Desa Wisata Samiran yang nantinya dapat digunakan sebagai data dasar untuk pengembangan agrowisata di Desa Wisata Samiran, khususnya sebagai peningkatan atensi akademisi program pendampingan/pengabdian masyarakat dari Grup Riset Pengelolaan DAS dan Agroekosistem, Fakultas Pertanian Universitas Sebelas Maret, serta para pihak yang berminat.
\end{abstract}

Kata Kunci: desa wisata, agrowisata, dataran tinggi, lereng merbabu-merapi

\section{Pendahuluan}

Pemanfaatan lahan dataran tinggi untuk pertanian menunjukkan kecenderungan (trend) yang terus meningkat, seiring dengan meningkatnya konversi lahan pertanian produktif di dataran rendah ke pemanfaatan non pertanian. Menurut Dariah (2007), sekitar 45\% dari wilayah Indonesia merupakan lahan dataran tinggi, perbukitan dan pegunungan.

Pemanfaatan lahan dataran tinggi untuk pertanian intensif sangat rawan erosi, walaupun mampu menghasilkan berbagai jenis tanaman seperti sayuran, tanaman pangan, tanaman buah, perkebunan, dan hasil peternakan. Lahan dataran tinggi, selain memberikan manfaat ekonomi bagi petani, juga berperan penting dalam menjaga fungsi lingkungan dan penyanga daerah dibawahnya. Desa Wisata Samiran berada pada lahan dataran tinggi di lembah Gunung Merbabu-Merapi Kecamatan Selo Kabupaten Boyolali Propinsi Jawa Tengah, merupakan desa paling atas di lereng Gunung Merbabu-Merapi sehingga juga berfungsi sebagai zone penyangga dari hutan Taman Nasional Gunung Merbabu-Merapi (TNG Merbabu-Merapi).

Hasil studi Suyana (2019), diperoleh bahwa permasalahan yang dihadapi petani di Desa Wisata Samiran adalah (a) degradasi lahan akibat erosi, dan (b) potensi sumberdaya lahan dataran tinggi yang dimiliki belum dikelola secara optimal untuk meningkatkan pendapatan petani.

\footnotetext{
*Penulis Korespondensi. Email: jokosuyonouns@staff.uns.ac.id
} 
Desa Wisata Samiran mempunyai luas 663,329 ha dengan tinggi tempat/ elevasi 1.400-2.550 m dpl, curah hujan diatas 2000-3000 mm/tahun, serta jenis tanah Andosol di lereng Merbabu dan tanah Regosol di lereng Merapi. Secara agroklimat Desa Wisata Samiran sangat berpotensi/sesuai untuk pengembangan beraneka agrowisata, yaitu meliputi tanaman perkebunan (teh dan kopi arabika), tanaman buah (tledung/kesemek, apel dan jeruk), tanaman hias, serta sayuran. Pengembangan agrowisata tersebut diharapkan mempunyai prospek ekonomi dan pasar yang dapat mendukung keberadaan Desa Wisata Samiran yang sudah dirintis sejak tahun 2006.

Desa wisata adalah suatu bentuk integrasi antara atraksi, akomodasi dan fasilitas pendukung yang disajikan dalam suatu struktur kehidupan masyarakat yang menyatu dengan tata cara dan tradisi yang berlaku (Nuryanti, 1993). Desa wisata mempunyai dua komponen utama, yaitu : (a) Atraksi : seluruh kehidupan keseharian penduduk setempat beserta setting fisik lokasi desa yang memungkinkan berintegrasinya wisatawan sebagai partisipasi aktif seperti kursus tari, bahasa, dan lain-lain yang spesifik; dan (b) Akomodasi : sebagian dari tempat tinggal para penduduk setempat dan atau unit-unit yang berkembang atas konsep tempat tinggal penduduk. Sehingga desa wisata merupakan wisata pedesaan (village-tourism) dimana sekelompok kecil wisatawan tinggal dalam atau dekat dengan suasana tradisional, sering di desa-desa yang terpencil dan belajar tentang kehidupan pedesaan dan lingkungan setempat.

Desa wisata Samiran memiliki sumberdaya lahan dataran tinggi pedesaan yang indah dengan panorama alam pegunungan dan gunung Merbabu-Merapi, sehingga pengembangan agrowisata merupakan pilihan yang tepat dan bijaksana. Agrowisata adalah aktivitas wisata yang melibatkan penggunaan lahan pertanian atau fasilitas terkait yang menjadi daya tarik bagi wisatawan. Agrowisata memiliki beragam variasi, yaitu seperti pembudidayaan buah dan sayuran, wisata petik buah (apel, jeruk, belimbing, strawberi), wisata kebun teh/kedai teh, wisata kebun salak, wisata kebun kopi/kedai kopi, labirin jagung, memberi makan hewan ternak, restoran ikan, dan lainnya. Agrowisata bertujuan untuk memperluas pengetahuan, pengalaman rekreasi, dan hubungan usaha di bidang pertanian. Melalui pengembangan agrowisata yang menonjolkan budaya lokal dalam memanfaatkan lahan, dapat meningkatkan pendapatan petani dan melestarikan sumber daya lahan, serta memelihara budaya maupun teknologi lokal yang umumnya sesuai dengan kondisi lingkungan alaminya. Menurut Wahyudi (2009), beberapa manfaat dari agrowisata, antara lain yaitu : (a) meningkatkan konservasi lingkungan, (b) meningkatkan nilai estetika dan keindahan alam, (c) memberikan nilai rekreasi, (d) meningkatkan kegiatan ilmiah dan pengembangan ilmu pengetahuan, serta (e) mendapatkan keuntungan ekonomi.

Keberhasilan pengembangan agrowisata di Desa Wisata Samiran lebih banyak tergantung pada "peran aktif" dari subyek pelaksana kegiatan pertanian/usahatani yaitu petani, kelompok tani, dan juga aparat desa. Untuk meningkatkan partisipasi petani dan aparat desa di dalam kegiatan pengembangan Desa Wisata Samiran, sebaiknya kelompok tani dapat bekerjasama dengan perguruan tinggi dan pemda/dinas terkait. Dengan keterlibatan perguruan tinggi, LSM, dan pemda/dinas terkait diharapkan pengetahuan petani dapat ditingkatkan, sehingga mampu berperan sebagai stabilisator dan daya pengembang agrowisata yang kondusif menuju Desa Wisata Samiran yang lebih asri, sejahtera, dan ramah lingkungan.

Berdasarkan pemikiran diatas, telah dilakukan kegiatan "Perintisan Pendampingan Pada Kelompok Tani Desa Wisata Samiran Di Kecamatan Selo Lereng Merbabu-Merapi" dengan tujuan untuk mengumpulkan data dan informasi yang berkaitan dengan Profil Desa Wisata Samiran.

\section{Metode Pelaksanaan}

Program pengabdian mandiri aktif ini telah dilakukan selama 8 bulan, yaitu dari bulan April s/d Desember 2019. Kegiatan dilakukan di Desa Wisata Samiran, Kecamatan Selo, Kabupaten Boyolali, Propinsi Jawa Tengah yang berada di lereng Merbabu-Merapi atau di lembah Gunung Merbabu-Merapi. 
Metode yang digunakan meliputi pengumpulan data sekunder dan primer, serta survei dilapangan yang berkaitan Profil Desa Wisata Samiran, yaitu meliputi (a) data/informasi kondisi agroklimat dan jenis usaha tani; (b) data/informasi keberadaan dan kegiatan kelompok tani; dan (c) data/informasi obyek wisata di Desa Samiran, Kecamatan Selo, Kabupaten Boyolali.

\section{Hasil dan Pembahasan}

\section{Kondisi Wilayah Di Desa Wisata Samiran}

Desa Wisata Samiran, Kecamatan Selo, Kabupaten Boyolali mempunyai luas wilayah 663,329 ha, berada di lembah gunung Merapi-Merbabu dengan elevasi 1.400 -2.550 $\mathrm{m}$ dpl dimana pada wilayah utara sampai lereng Gunung Merbabu pada elevasi $2.450 \mathrm{~m} \mathrm{dpl}$, dan wilayah selatan sampai lereng gunung Merapi pada elevasi $2.550 \mathrm{~m} \mathrm{dpl}$; dan secara geografi berada pada $7^{0} 28^{0} 20^{\circ} \mathrm{LS}-7^{0} 31^{0} 55^{\circ} \mathrm{LS}$ dan $110^{\circ} 26^{0} 20^{\circ} \mathrm{BT}-110^{0} 28^{0} 42^{0} \mathrm{BT}$ (Gambar 1).

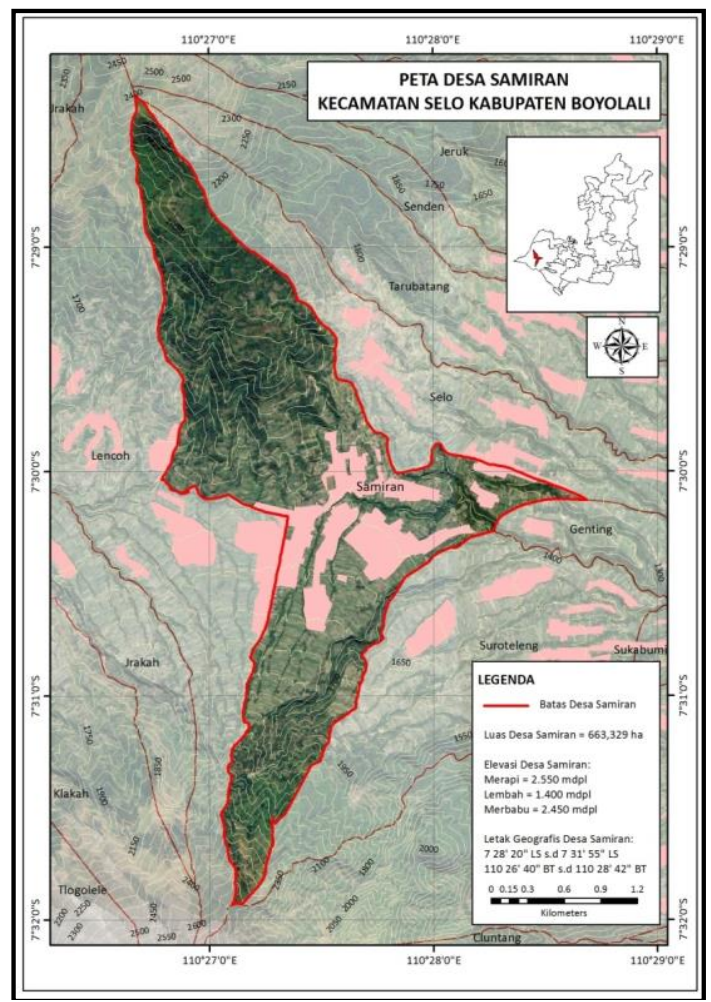

Gambar 1. Peta wilayah Desa Samiran, Kecamatan Selo, Kabupaten Boyolali

Secara umum Desa Wisata Samiran memiliki curah hujan tahunan diatas 2.000-3.000 mm/tahun, dengan suhu udara yang sejuk berkisar $10,7-17,7{ }^{\circ} \mathrm{C}$, serta sumberdaya lahan dibagian utara (lereng Merbabu) mempunyai jenis tanah Andosol dan dibagian selatan (lereng Merapi) mempunyai jenis tanah Regosol. Tanah Regosol ini bahan induknya berasal dari erupsi gunung Merapi, berwarna kelabu, tekstur tanah kasar (kadar pasir lebih $60 \%$ ), struktur remah/kersai, konsistensi lepas sampai gembur, belum membentuk agregat, $\mathrm{pH}$ tanah 6-7, secara umum cukup mengandung unsur $\mathrm{P}$ dan $\mathrm{K}$ masih segar/belum siap diserap tanaman, tetapi kekurangan $\mathrm{N}$, dan untuk mempercepat pelapukan diperlukan pupuk organik/pupuk kandang/pupuk hijau. Sedangkan untuk tanah Andosol bahan induknya berasal dari erupsi gunung Merbabu, berwarna hitam/kelam, banyak mengandung mineral amorf dari abu vulkan, kandungan bahan organik tinggi, struktur tanah remah, konsistensi gembur, tekstur tanah (sedang-halus), reaksi tanah (agak masam-netral), dan mineral liat sebagian besar alofan. 
Jurnal SEMAR Vol. 9 No. 1, hal. $27-35$

ISSN: 2302-3937 | Copyright (C LPPM Universitas Sebelas Maret Homepage: https://jurnal.uns.ac.id/jurnal-semar

\section{Karakteristik Lahan di Desa Wisata Samiran}

Kondisi lahan usahatani di wilayah Desa Wisata Samiran secara umum mempunyai kemiringan lereng : 0-3\% (datar), 3-8\% (landai), 8-15\% (bergelombang), 15-30 (berbukit), 30-45\% (bergunung), dan $>45 \%$ (curam dan sangat curam) sebagaimana ditunjukkan pada Gambar 2. Jenis usahatani yang dilakukan petani berupa tanaman semusim (tembakau dan jagung), sayuran (wortel, bawang daun, kubis, brokoli, boncis, sawi, jepan, dan lainya), serta tanaman buah (tledung/kesemek). Pada lahan yang memiliki kemiringan di atas $15 \%$, karena petani dalam mengelola lahannya kurang atau tidak memperhatikan kaidah konservasi tanah dan air (seperti guludan searah lereng) telah menyebabkan masalah erosi yang serius dan degradasi lahan.
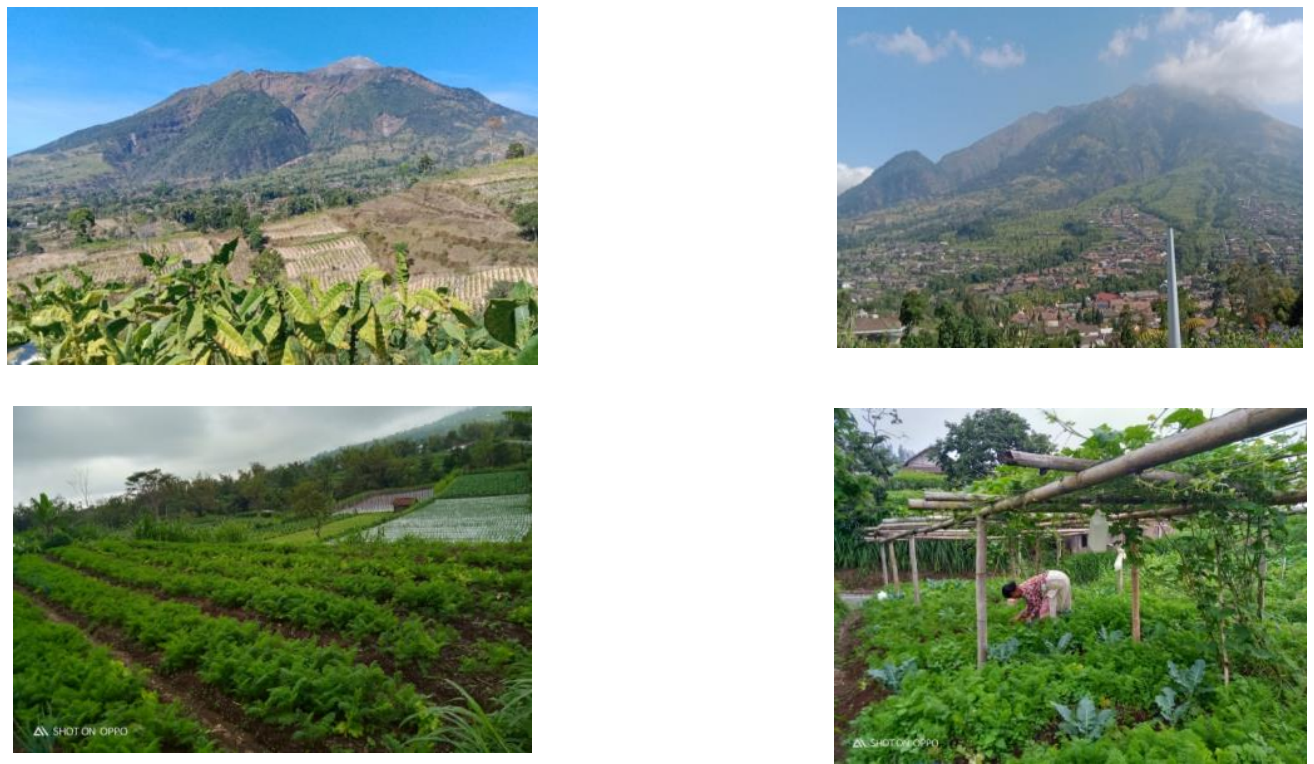

Kondisi lahan di Desa Samiran yang berada di lereng Merapi
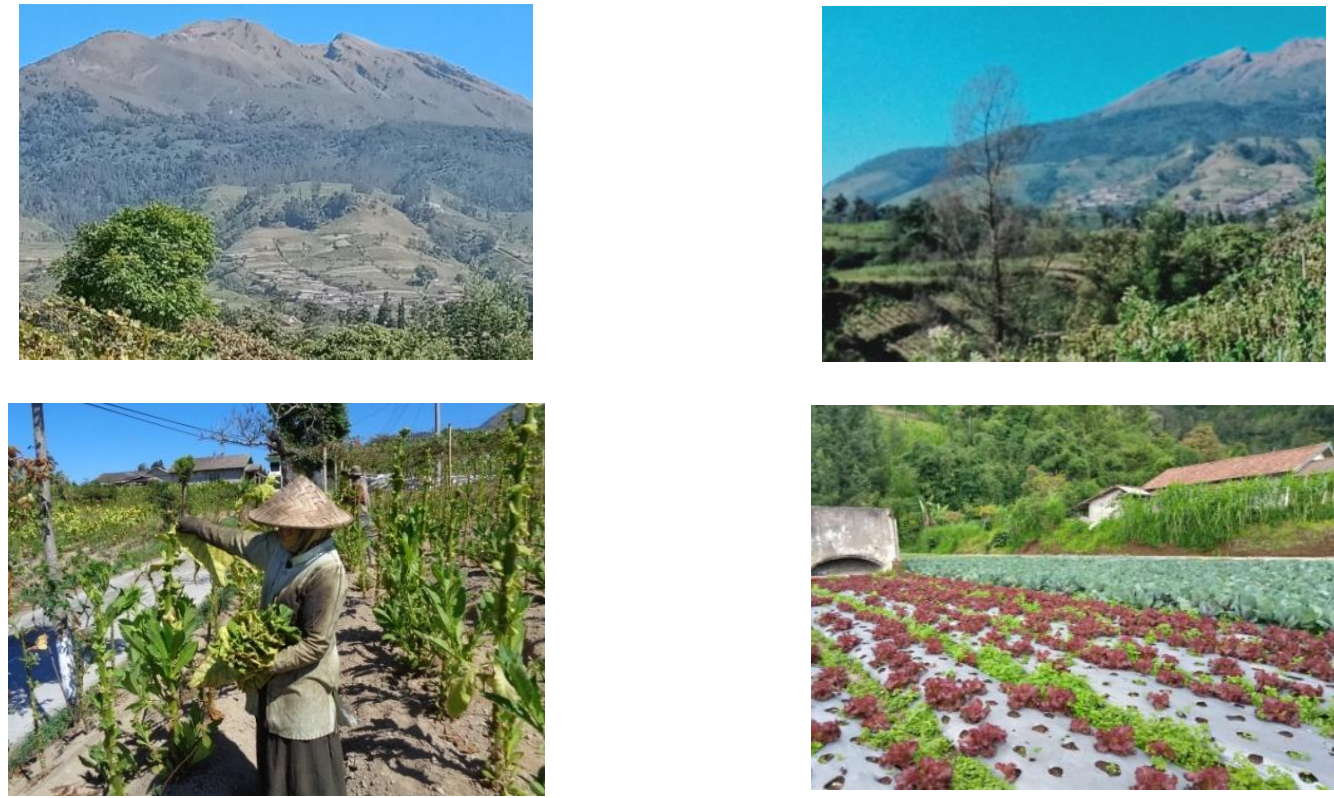

Kondisi lahan di Desa Samiran yang berada di lereng Merbabu

Gambar 2. Kondisi lahan di Desa Wisata Samiran yang berada di lereng Merapi dan Merbabu

Secara umum sumberdaya lahan di lereng Merbabu (bahan induknya dari erupsi gunung Merbabu) mempunyai jenis tanah Andosol, sedangkan di lereng Merapi (bahan induknya dari erupsi gunung Merapi) mempunyai jenis tanah Regosol atau Ordo Entisols (Taksonomi Tanah USDA, 2014). Tanah Andosol atau Ordo Andisols 
(Taksonomi Tanah USDA, 2014), merupakan tanah yang mempunyai sifat-sifat tanah andik $60 \%$ atau lebih pada ketebalannya, secara umum berwarna hitam (lapisan atas berwarna hitam-coklat kekelabuan dan lapisan bawah berwarna coklat-coklat kekuningan), banyak mengandung mineral amorf atau lebih $60 \%$ terdiri dari abu vulkanik (vitrik, cinders, atau pyroklastik), bulk density kurang $0,90 \mathrm{~g} / \mathrm{cm}^{3}$, kandungan bahan organik tinggi, struktur tanah remah, konsistensi gembur, tekstur tanah (sedang-halus), reaksi tanah (agak masamnetral), mineral liat sebagian besar alofan dan apabila makin berkembang mengandung juga haloisit. Biasanya berada pada ketinggian tempat (elevasi) di atas 700/1000 $\mathrm{m}$ dpl, dengan bentuk wilayah dari datar-bergunung. Secara umum baik untuk budidaya hortikultura (buah dan sayuran), teh, kopi, dan tembakau (Darmawijaya, 1990; Hardjowigeno, 2003). Andosol di lereng Gunung Merbabu ini berasal dari tufa vulkanik tersusun andesit, mengandung augit dan hipersten (Suyana, 2019).

Secara agroklimat lahan dataran tinggi dengan tanah Andosol/Andisols diwilayah Desa Wisata Samiran cocok/sesuai untuk pengembangan beraneka agrowisata, diantaranya yaitu (a) tanaman perkebunan seperti teh dan kopi arabika; (b) tanaman buah seperti tledung/kesemek, strawbery, apel (Apel Malang, Apel India), dan jeruk (Jeruk Keprok Malang/Batu-55); (c) tanaman hias seperti senduro, cemoro sabinah, bambu cendani, dahlia, talas gunung, dan lainnya; serta (d) sayuran seperti kubis, bunga kol milky dan brokoli, wortel merah, kentang, bawang daun, dan lainnya. Berdasarkan potensi tersebut maka diharapkan peran perguruan tinggi, LSM, dan pemda/dinas terkait ikut berkontribusi di dalam program-program pendampingan kepada kelompok tani di Desa Wisata Samiran untuk pengembangan agrowisata yang telah ada maupun dengan jenis tanaman introduksi (didatangkan dari daerah lain). Dengan keterlibatan perguruan tinggi/LSM/dinas terkait diharapkan pengetahuan petani dapat ditingkatkan, sehingga mampu berperan sebagai stabilisator dan daya pengembang beraneka agrowisata yang kondusif menuju Desa Wisata Samiran yang lebih asri, sejahtera, dan ramah lingkungan.

\section{Keberadaan dan Kegiatan Kelompok Tani di Desa Wisata Samiran}

Hasil informasi dari aparat desa, kelompok tani dan petani di Desa Samiran, diperoleh bahwa keberadaan Desa Wisata Samiran sudah dirintis sejak tahun 2006 dan terdiri dari 12 dukuh. Pada saat ini telah memiliki 11 kelompok tani yaitu : (a) Kelompok Tani agrowisata (Salaka, Argo-Mulyo, Ngudi-Rejeki, Ngudi-Rahayu, dan Manunggal); (b) Kelompok Taruna Tani (Subur dan Bina-Usaha); (c) Kelompok Wanita Tani (TentremRahayu, Samiran-Asri, Subur-Makmur, Loncang, dan Berdaya); dan (d) Kelompok Tani perkebunan kopi yang tergabung di Gapoktan Tsamarun Jabalaini.

Secara umum komoditas pertanian yang telah dikembangkan oleh petani dan kelompok tani meliputi : (a) tanaman sayuran (kubis, cabe, tomat, bawang merah, kentang, wortel, loncang/bawang daun, seledri, bunga kol brokoli, dan bunga kol milky); (b) tanaman buah (tledung/kesemek, jeruk nipis, dan strawbery); serta (c) tanaman hias (senduro, cemoro sabinah, bambu cendani, manis rejo, dahlia, pendowo, talas gunung, dewandaru, cepoko gondok, cepoko mulyo, cepoko api, dan panca warna).

Adapun jenis usaha yang telah ada dan dikelola oleh petani dan kelompok tani diantaranya : (a) pembibitan dalam pesemaian beberapa jenis tanaman sayuran, buah, dan bunga/hias; (b) penjualan beberapa jenis tanaman sayuran, buah, dan bunga; (c) penyediaan lahan pertanian sebagai tujuan wisata khusus (praktek/penelitian ilmiah); (d) pemasaran hasil (produk olahan) dari tanaman sayuran dan buah dengan kemasan cantik (kripik brokoli, kripik bayam merah, kripik jepan, sale tledung, kopi arabika tubruk dan giling halus).

Introduksi tanaman kopi arabika di Desa Samiran sudah dimulai sejak tahun 2002, saat ini disamping sudah berproduksi, juga sudah dapat menimbulkan kesadaran petani terutama dari Gapoktan Tsamarun Jabalaini untuk membuat pembibitan sendiri (Gambar 3), serta pasca panen hasil tanaman kopi arabika menjadi kopi tubruk dan giling halus (Gambar 4). 


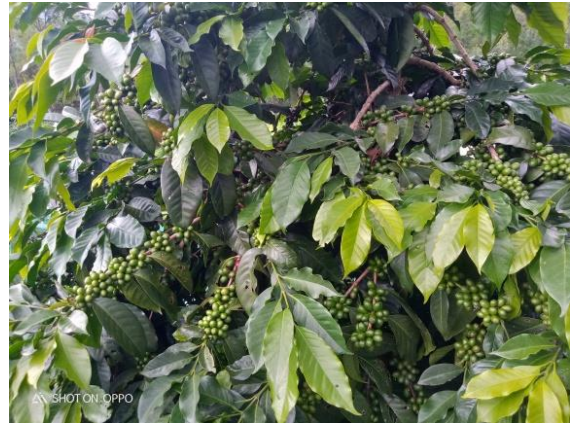

Tanaman kopi arabika

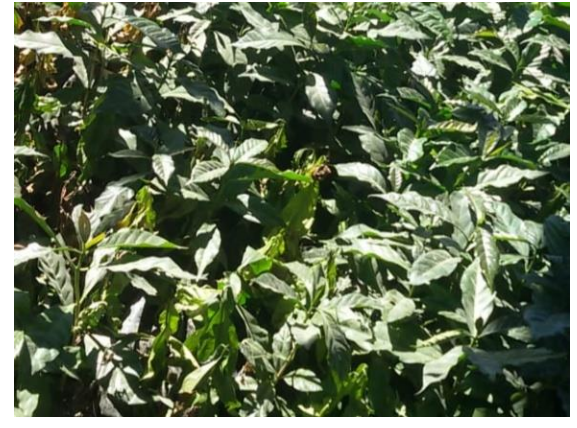

Pembibitan kopi arabika

Gambar 3. Tanaman dan pembibitan kopi arabika di Desa Wisata Samiran
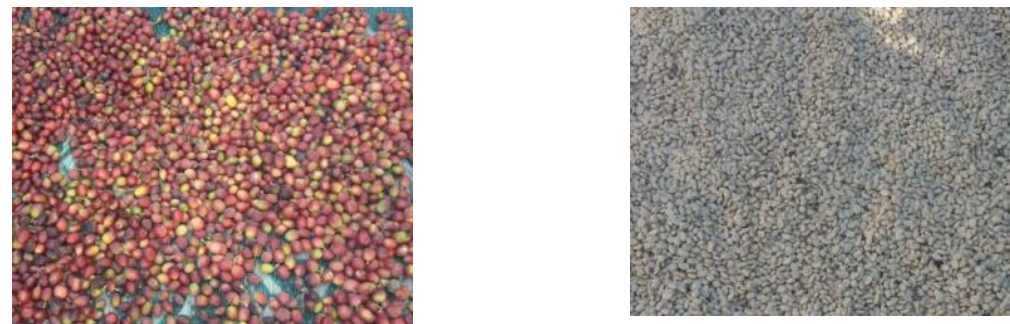

Biji (kiri) dan Ose (kanan) kopi arabika hasil petani Gapoktan Tsamarun

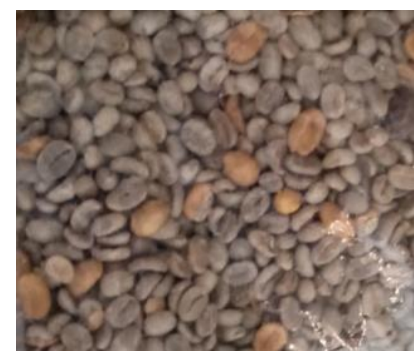
Jabalaini

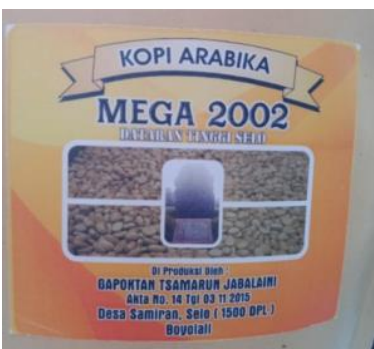

Kopi arabika tubruk dan giling halus hasil olahan Bp. Sutrisno harga Rp.

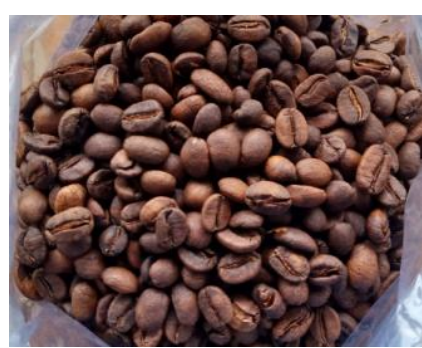
$30.000,-$ /ons
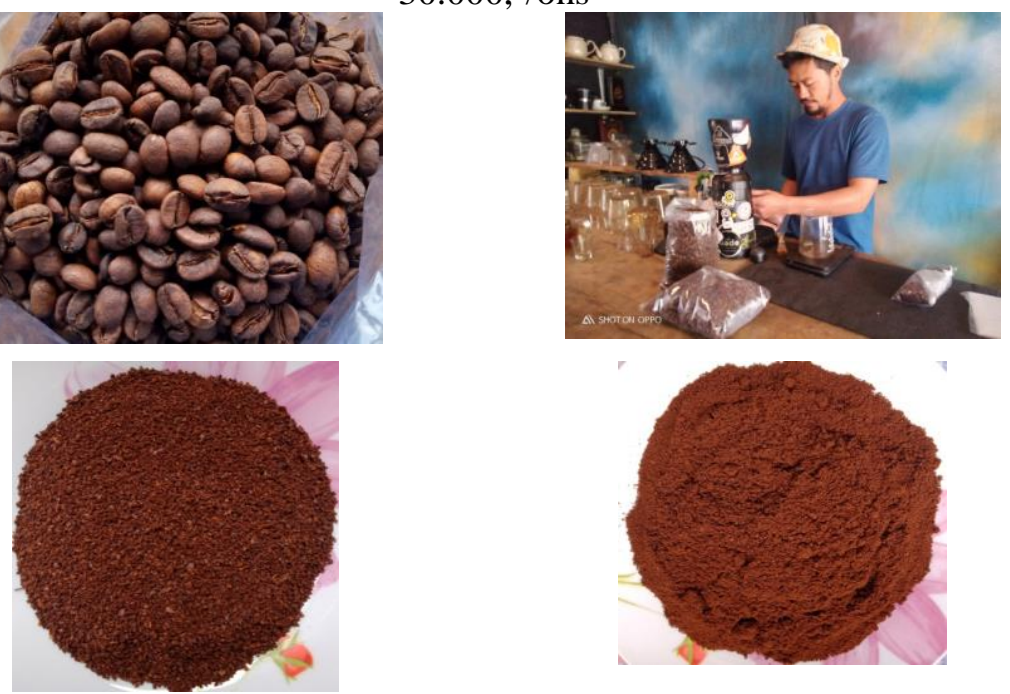

Kopi arabika tubruk (kiri) dan giling halus (kanan)

hasil olahan Mas Hery harga Rp. 40.000,-/ons di Desa Wisata Samiran

Gambar 4. Hasil kopi arabika dan kedai kopi arabika khas Desa Wisata Samiran 


\section{Keberadaan Obyek Wisata di Desa Wisata Samiran}

Keberadaan obyek-obyek wisata di Desa Samiran Kecamatan Selo termasuk bagian dari Peta Wisata Kabupaten Boyolali (Gambar 5). Pada Gambar 5, diperlihatkan peta wisata Kabupaten Boyolali pada No. 7 yaitu : Arga Merapi-Merbabu, Gua Raja, Joglo I \& II, Uga I \& II, Pasar Bubrah, dan Pasar Tradisional Selo.

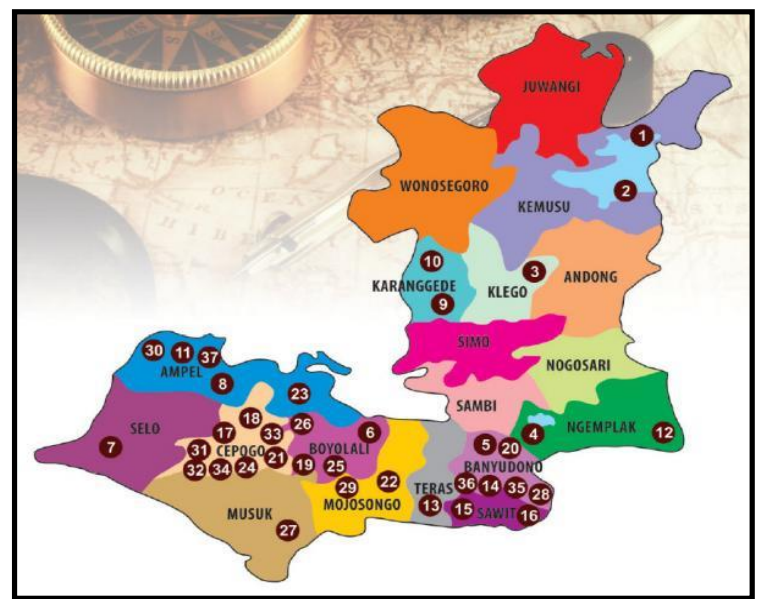

Gambar 5. Peta Wisata Kabupaten Boyolali Terbaru (2020)

Keberadaan beberapa obyek wisata di Desa Wisata Samiran adalah merupakan bagian dari obyek wisata "Arga Merapi-Merbabu". Desa Wisata Samiran berada di lembah Gunung Merbabu-Merapi merupakan kawasan pedesaan di dataran tinggi yang memiliki pesona dan panaroma alam pegunungan/gunung yang indah menakjubkan dengan udara yang sejuk, tetapi masih tersembunyi dan masih banyak orang yang belum mengetahuinya. Obyek wisata yang ada di Desa Wisata Samiran (Gambar 6) meliputi situs sejarah dan budaya, spot foto panorama alam yang indah/menakjubkan Gunung Merbabu dan Gunung Bibi-Merapi, serta pertanian; diantaranya yaitu Petilasan Ki Ageng Kebo Kanigoro, Alam Sutera, Merapi Garden, Gardu Pandang New Selo, Tretes Taman Tani (Triple T), dan Embung Manajar.
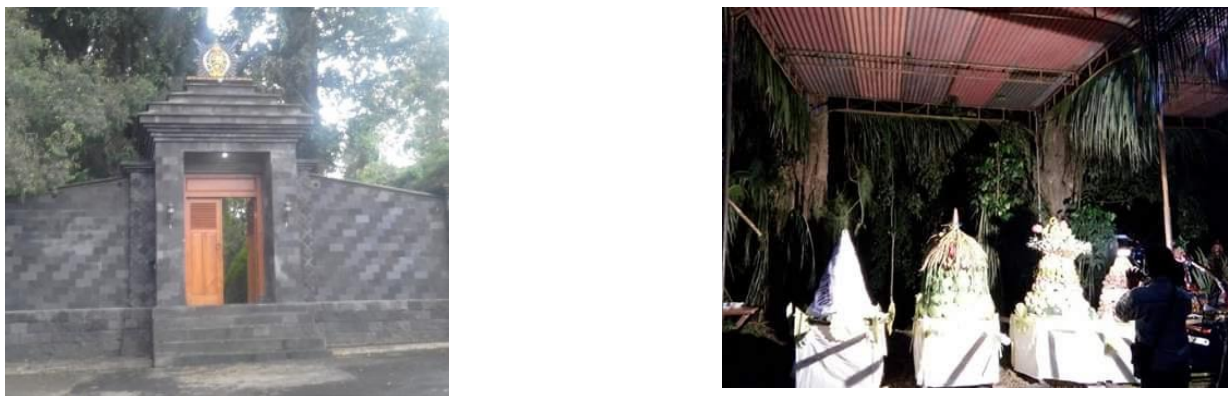

Petilasan Ki Ageng Kebo Kanigoro situs sejarah dan budaya
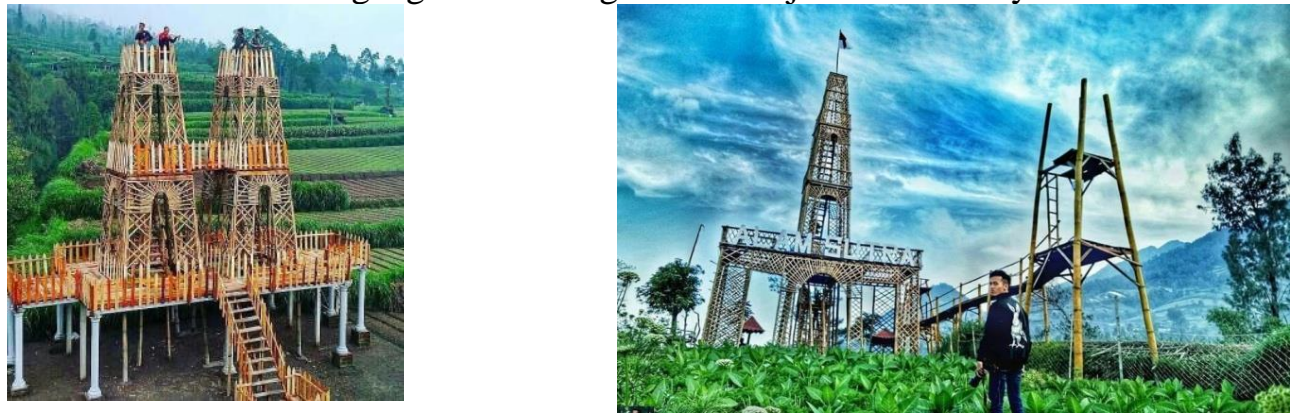

Obyek wisata Alam Sutera 

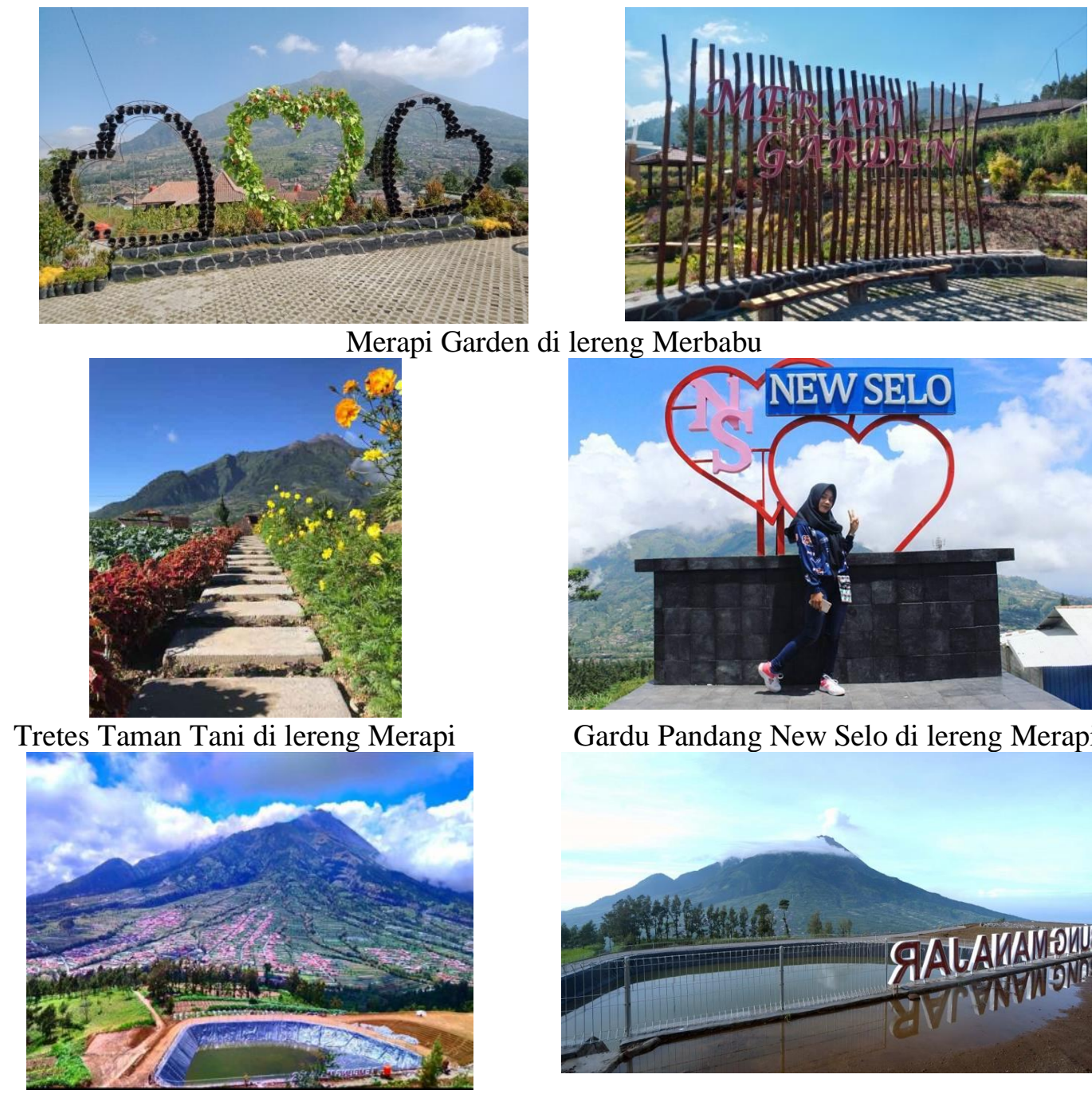

Merapi Garden di lereng Merbabu
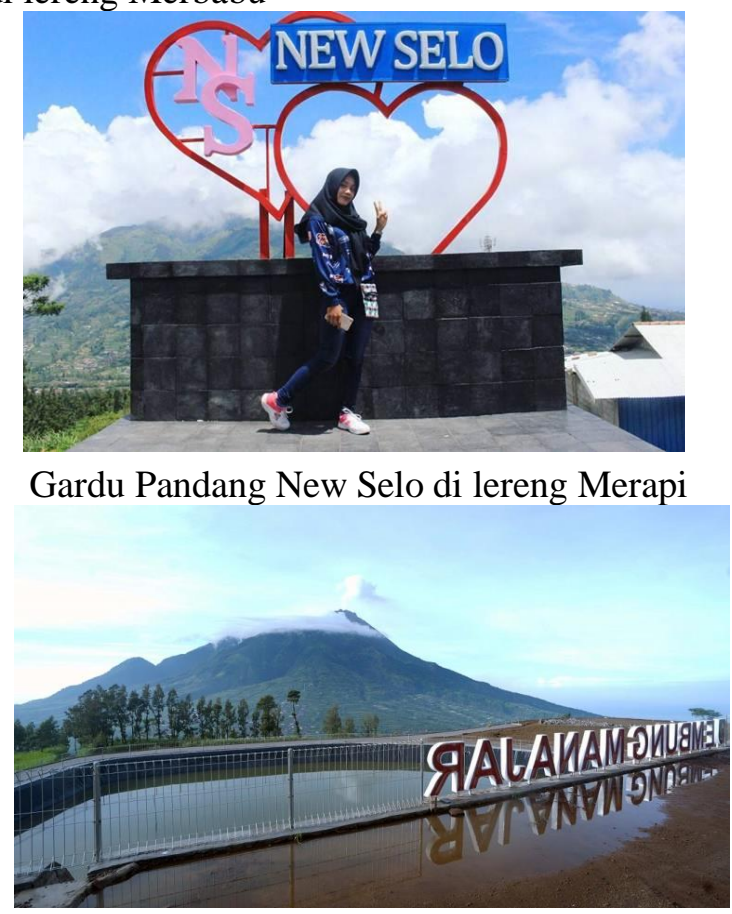

Embung Manajar di lereng Merbabu

Gambar 6. Obyek-obyek wisata di Desa Wisata Samiran, Kec. Selo, Kab. Boyolali

\section{Penutup}

1. Desa Wisata Samiran secara agroklimat cocok/sesuai untuk pengembangan beraneka agrowisata tanaman perkebunan (teh dan kopi arabika), tanaman buah (tledung/kesemek, apel, dan jeruk), tanaman hias, dan sayuran.

2. Keberadaan kelompok tani di Desa Wisata Samiran sudah cukup baik, namun perannya untuk pengembangan agrowisata masih perlu ditingkatkan lagi.

3. Desa Wisata Samiran memiliki obyek wisata berupa situs sejarah dan budaya, spot foto panorama alam Gunung Merbabu-Merapi, serta pertanian.

\section{Saran}

1. Untuk peningkatan atensi akademisi Grup Riset Pengelolaan DAS dan Agroekosistem, Fakultas Pertanian UNS dapat ikut berkontribusi di dalam pengembangan agrowisata di Desa Wisata Samiran.

2. Perguruan tinggi, LSM, dan instansi terkait diharapkan ikut berkontribusi untuk pengembangan Desa Wisata Samiran yang lebih asri dan ramah lingkungan. 
Jurnal SEMAR Vol. 9 No. 1, hal. $27-35$

ISSN: 2302-3937 | Copyright @ LPPM Universitas Sebelas Maret

Homepage: https://jurnal.uns.ac.id/jurnal-semar

\section{Ucapan Terima Kasih}

Ucapan terimakasih kepada pihak-pihak yang telah membantu terlaksananya kegiatan program Pengabdian Masyarakat Mandiri Aktif dengan judul Perintisan Pendampingan Pada Kelompok Tani "Desa Wisata Samiran" Di Kecamatan Selo Lereng Merbabu-Merapi.

\section{Referensi}

Darmawijaya, M, Isa. 1990. Klasifikasi tanah : Dasar teori bagi peneliti tanah dan pelaksana pertanian di Indonesia. Balai Penelitian Teh dan Kina Gambung, Bandung. 278 p.

Dariah, A. 2007. Budidaya Pertanian Pada Lahan Pegunungan. Warta Penelitian dan Pengembangan Pertanian Indonesia. 29 (1): 7-9.

Hardjowigeno, S. 2003. Klasifikasi Tanah dan Pedogenesis. Edisi Revisi. Penerbit Akademika Pressindo. Jakarta. 354 p.

Nuryanti, W. 1993. Concept, Perspective and Challenges. In. Laporan Konferensi Internasional Pariwisata Budaya. Gadjah Mada University Press. Yogyakarta. Hal. 2-3.

Soil Survey Staff. 2014. Kunci Taksonomi Tanah. Edisi Ketiga, 2015. Balai Besar Penelitian dan Pengembangan Sumberdaya Lahan Pertanian, Badan Penelitian dan Pengembangan Pertanian.

Suyana, J. 2019. Perintisan Pendampingan Pada Kelompok Tani Desa Wisata Samiran di Kecamatan Selo Lereng Merbabu-Merapi. Laporan Akhir. Pengabdian Masyarakat Mandiri Aktif. Fakultas Pertanian, UNS Surakarta.

Peta Wisata Kabupaten Boyolali Terbaru. 2020. http://www.eventsolo.com/Wisata/Boyolali/ Peta-WisataKabupaten-Boyolali-Terbaru.html. 2020-02-27.

Wahyudi, I. 2009. Strategi Bauran Pemasaran Dengan Penerapan Metode Proses Hierarki Analitik di Agrowisata Little Farmers Lembang, Bandung. Skripsi. Departemen Agribisnis, FEM. IPB. Bogor. 